NASA Technical Memorandum 106495

2599

AIAA-94-2565

$12 p$

\title{
The Nozzle Acoustic Test Rig; An Acoustic and Aerodynamic Free-Jet Facility
}

Raymond S. Castner

Lewis Research Center

Cleveland, Ohio

Prepared for the

18th AIAA Aerospace Ground Testing Conference

sponsored by the American Institute of Aeronautics and Astronautics

Colorado Springs, Colorado, June 20-23, 1994
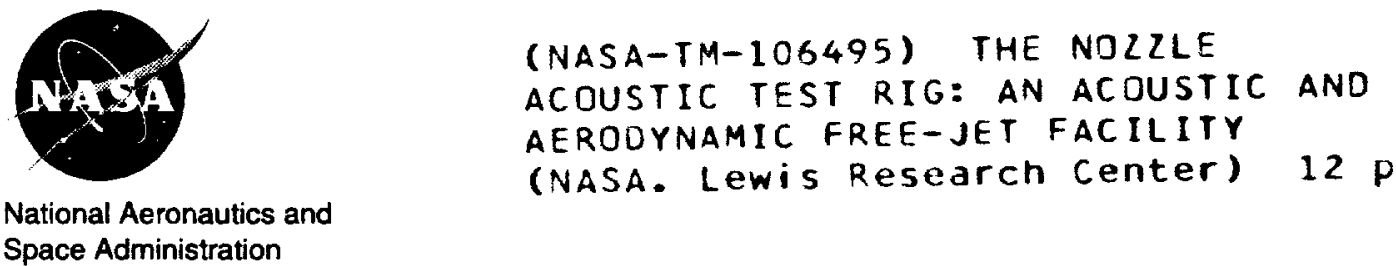

N94-28749 
Trade names or manufacturers' names are used in this report for identification only. This usage does not constitute an official endorsement, either expressed or implied, by the National Aeronautics and Space Administration. 


\title{
THE NOZZLE ACOUSTIC TEST RIG; AN ACOUSTIC AND AERODYNAMIC FREE-JET FACILITY
}

\author{
Raymond S. Castner \\ National Aeronautics and Space Administration \\ Lewis Research Center \\ Cleveland, Ohio
}

\begin{abstract}
$\underline{\text { Abstract }}$
The Nozzle Acoustic Test Rig (NATR) was built at NASA Lewis Research Center to support the High Speed Research Program. The facility is capable of measuring the acoustic and aerodynamic performance of aircraft engine nozzle concepts. Trade-off studies are conducted to compare performance and noise during simulated low-speed flight and takeoff.

Located inside an acoustically treated dome with a 62-ft radius, the NATR is a free-jet that has a 53-in. diameter and is driven by an air ejector. This ejector is operated with $125 \mathrm{lb} / \mathrm{s}$ of compressed air, at $125 \mathrm{psig}$, to achieve $375 \mathrm{lb} / \mathrm{s}$ at Mach 0.3. Acoustic and aerodynamic data are collected from test nozzles mounted in the free-jet flow. The dome serves to protect the surrounding community from high noise levels generated by the nozzles, and to provide an anechoic environment for acoustic measurements.

Information presented in this report summarizes free-jet performance, fluid support systems, and data acquisition capabilities of the NATR.
\end{abstract}

\section{Introduction}

The High Speed Research (HSR) program at NASA is aimed at developing technology for a next generation High Speed Civil Transport (HSCT). This aircraft would carry 300 passengers at speeds over Mach 2. Major obstacles in the development of the HSCT are nitrogen oxide $\left(\mathrm{NO}_{\mathrm{x}}\right)$ emissions, which harm the Earth's upper atmosphere, and takeoff noise. The HSR program at NASA has developed test programs to look for solutions to these problems.

A new facility at NASA's Lewis Research Center was built to investigate acoustic and low-speed aerodynamic performance of advanced nozzle concepts for the HSCT. The 9 - by 15 -ft Low-Speed Wind Tunnel was the only existing facility at NASA Lewis capable of testing both low-speed performance and acoustics. Because of the heavy demand from other programs, the acoustic capabilities of the Low-Speed Wind Tunnel were limited to nearfield studies. To solve these limitations, a new facility was built to measure acoustic and aerodynamic performance of HSR nozzles under low-speed and takeoff conditions. This facility, named the Nozzle Acoustic Test Rig (NATR), is a Mach 0.3 free-jet wind tunnel capable of measuring the aerodynamic and acoustic performance of HSCT nozzle concepts at $1 / 10$ scale.

Located near the existing Powered Lift Rig at NASA Lewis, the NATR uses an existing high pressure air system to drive the free-jet. This location takes advantage of an acoustic dome, designed to shield test nozzle noise levels from surrounding communities. This report reviews the existing capabilities of the NATR, its support systems, and the design of the acoustic dome.

\section{Aerodynamic Capabilities}

Designed by the Engineering Directorate at NASA Lewis, the primary purpose of the NATR free-jet is to provide an airflow of Mach 0.3 at the exit plane of a 53-in.-diameter test duct. HSR test nozzles are mounted in this duct to simulate low-speed forward flight. In a typical test situation, the test nozzle exit plane is $2 \mathrm{ft}$ downstream of the duct exit. HSR nozzle concepts are evaluated for aerodynamic and acoustic performance. Accurate measurement of these parameters require the NATR free-jet to possess a uniform airflow profile and acceptable noise levels.

To achieve these free-jet properties, NATR design goals specified a uniform flow profile with $<1$ percent pressure distortion, and $<1$ percent turbulence intensity. In addition, the design specified that free-jet noise levels should not exceed $100 \mathrm{~dB}$. Noise levels from a typical HSR test nozzle range from 120 to $130 \mathrm{~dB}$; accurate measurement requires background noise levels to be 20 to $30 \mathrm{~dB}$ less than test levels. To test HSR nozzle concepts at $1 / 10$ scale, low background noise levels must be maintained over a frequency range of 50 to $100000 \mathrm{~Hz}$.

\section{NATR Free-Jet}

Free-jet airflow is driven through the test duct by an annular air ejector. Primary airflow into this ejector is supplied by a 125 psig combustion air source at a rate of $125 \mathrm{lb} / \mathrm{s}$. This air, supplied by a central source at NASA Lewis, was originally installed to support Powered Lift Rig testing. Access to this source reduced installation and operating costs for the new NATR facility.

A total airflow of $375 \mathrm{lb} / \mathrm{s}$ provides an airflow of Mach 0.3 in the 53 -in.-diameter test duct. In this configuration, $125 \mathrm{lb} / \mathrm{s}$ of primary air is used to entrain $250 \mathrm{lb} / \mathrm{s}$ of 


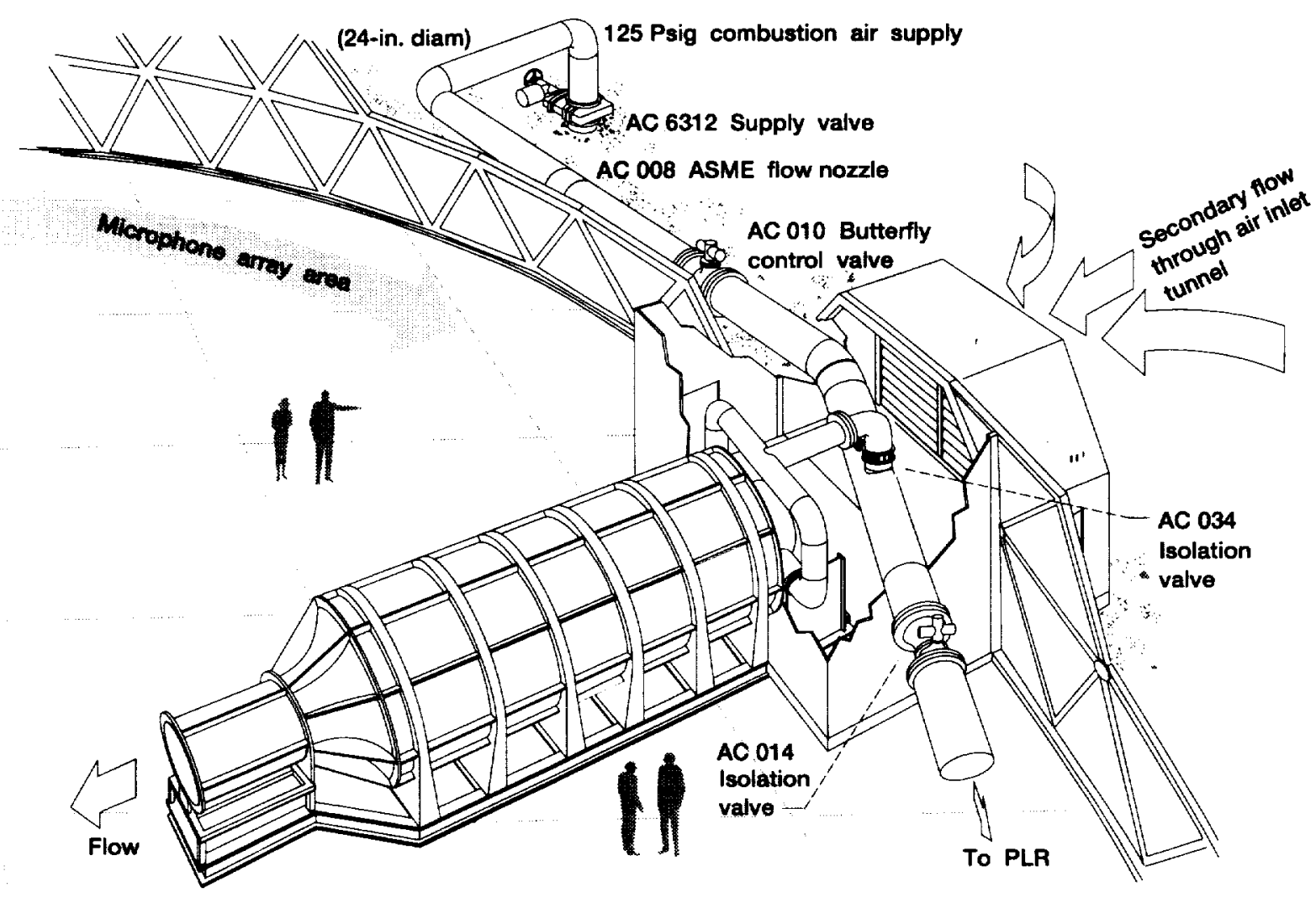

Figure 1.-Nozzle Acoustic Test Rig (NATR).

secondary airflow. The air ejector augments mass flow to efficiently provide large volumes of air. ${ }^{1}$ The energy needed to supply an airflow of $125 \mathrm{lb} / \mathrm{s}$ to the ejector is considerably less than that required to supply the entire airflow of $375 \mathrm{lb} / \mathrm{s}$ with a fan or compressor.

As shown in Fig. 1, the primary air is supplied through a 24-in. pipe, fitted with the gate valve labeled AC6312. Airflow is measured with a flow-measuring nozzle, approved by the ASME, that has a 9.126-in diameter and is accurate to within \pm 0.5 percent of the measured flow. Airflow rates are controlled with a 16 -in. butterfly valve (labeled $\mathrm{ACO10}$ ) and routed through an isolation valve (labeled AC034) to the NATR primary nozzle array. Thirty primary nozzles, each having a 1.66-in. diameter, are contained in this annular-shaped array (see Fig. 2). Highvelocity primary air exits these nozzles into an annular mixing section. This mixing section consists of an outer pressure vessel and a concentric centerbody, which are aerodynamically designed to enhance the ejector pumping action. Pumping action is created by the low-pressure highvelocity primary air, which draws ambient secondary air into the mixing section.

The mixed primary and secondary airflow expands in the diffuser, with a half-angle expansion of $6^{\circ}$. Downstream of the diffuser, the airstream enters a settling chamber that is $10 \mathrm{ft}$ in diameter. This chamber contains a honeycomb made up of cells $3 / 8$-in. across by $41 / 2$-in. thick, which removes large-scale turbulence. A flow screen of size 10 mesh, which has 60 percent open area, is located downstream of the honeycomb. This screen creates a pressure drop and improves flow uniformity. An ASME contoured bellmouth accelerates the flow from the settling chamber to the 53-in.diameter test section.

To design for desired noise levels, surfaces throughout the annular diffuser and settling chamber are treated with an acoustic liner. The liner absorbs the primary nozzle noise, which may travel through the facility before reaching the

TABLE I.-EJECTOR ACOUSTIC TREATMENT

\begin{tabular}{|c|c|c|c|}
\hline Section & $\begin{array}{l}\text { Screen types } \\
\text { (a) }\end{array}$ & $\begin{array}{l}\text { Perforated } \\
\text { metal type } \\
\text { (a) }\end{array}$ & $\begin{array}{l}\text { KEVLAR } \\
\text { treatment } \\
\text { (b) }\end{array}$ \\
\hline $\begin{array}{l}\text { Plenum and } \\
\text { diffuser }\end{array}$ & $\begin{array}{l}\text { Size } 18 \text { mesh } \\
0.009 \text {-in. wire diam. } \\
70.4 \% \text { open area }\end{array}$ & $\begin{array}{l}16 \text { gage }(0.0595 \text { in. }) \\
1 / 8 \text {-in.-diam. holes } \\
3 / 16 \text {-in. staggered } \\
\text { centers } \\
40 \% \text { open area }\end{array}$ & $0.45 \mathrm{lb} / \mathrm{ft}$ \\
\hline $\begin{array}{l}\text { Radial flow } \\
\text { splitters }\end{array}$ & $\begin{array}{l}\text { Size } 20 \text { mesh } \\
0.008 \text {-in. wire diam. } \\
70.6 \% \text { open area }\end{array}$ & $\checkmark$ & $1.12 \mathrm{lb} / \mathrm{ft}^{3}$ \\
\hline
\end{tabular}

aMade from type 304 stainless steel.

$b_{\text {Using No. } 29 \text { staple aramid fibers. }}$ 


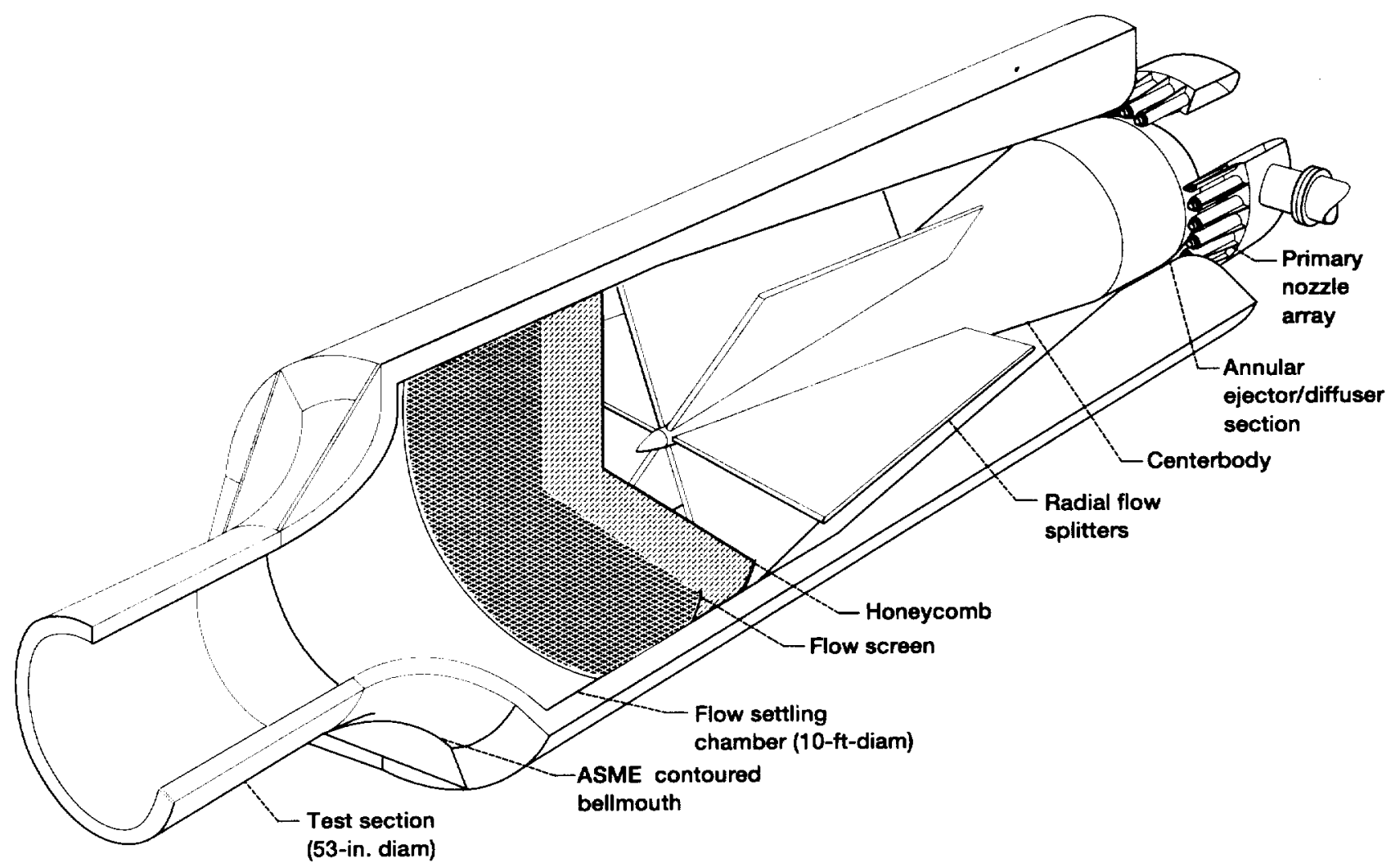

Figure 2.-Free-jet cutaway from the NATR.

test duct. The liner serves to keep free-jet noise levels 20 to $30 \mathrm{~dB}$ below the noise levels of HSR test nozzles. The acoustic liner is constructed of perforated metal backed with wire screen. This liner covers cavities filled with KEVLAR* aramid fibers to absorb acoustic energy. The six radial flow splitters used to hold the centerbody, are also treated to improve acoustic absorption. Table I contains a summary of the liner construction used in each section of the NATR.

\section{Jet Exit Rig Test Model}

The NATR was designed to test HSR nozzles with the Jet Exit Rig engine simulator. The Jet Exit Rig is a wind tunnel model used to test HSR nozzle concepts at $1 / 10$ scale. The rig is compatible with all wind tunnels at NASA Lewis and the NATR free-jet; it is designed to operate in free-stream flows with speeds to Mach 3.

Figure 3 shows the overall Jet Exit Rig configuration. Important capabilities of the Jet Exit Rig include the ability to simulate jet engine airflow and the ability to measure nozzle performance.

The engine simulator is capable of creating the hot core flow, and the cold bypass flow of advanced jet engines. A core flow of $14 \mathrm{lb} / \mathrm{s}$ can be generated with a hydrogen combustor. This provides simulated engine core flows to a maximum nozzle pressure ratio (NPR) of 4.5 at $2000{ }^{\circ} \mathrm{R}$. Engine bypass flow, of rates to $14 \mathrm{lb} / \mathrm{s}$, can be added to simulate turbojet or mixed turbofan flow. Figure 4 details the geometry of the Jet Exit Rig engine simulator. Test nozzles utilizing core flow only are limited to nominal exit areas of 8 in. $^{2}$; those utilizing mixed flow can be up to 13 in. $^{2}$. Drawings of this hardware are available to assist in the design of future nozzles intended for use with the Jet Exit Rig.

The Jet Exit Rig also includes instrumentation to measure nozzle performance. A thrust balance measures six components: axial force, normal force, side force, pitch moment, roll moment, and yaw moment. Aerodynamic instrumentation monitors nozzle airflow and temperature.

Nozzle testing with the Jet Exit Rig uses many fluid support systems available at NATR. These systems are discussed in the next section.

\section{Test Model Fluid Systems}

The fluid systems available for test programs at NATR are summarized in Table II. A detailed discussion of these systems is included in this report.

\section{Compressed Air System}

Compressed air is supplied to the NATR at a pressure of $450 \mathrm{psig}$ through a 10 -in.-diameter pipe (Fig. 5). The facility supply valve, designated AC6316, is a motor controlled butterfly valve operated from the Central Control Building at Lewis. Air is passed through a filter (AC200)

" KEVLAR is a product of DuPont Corporation, 


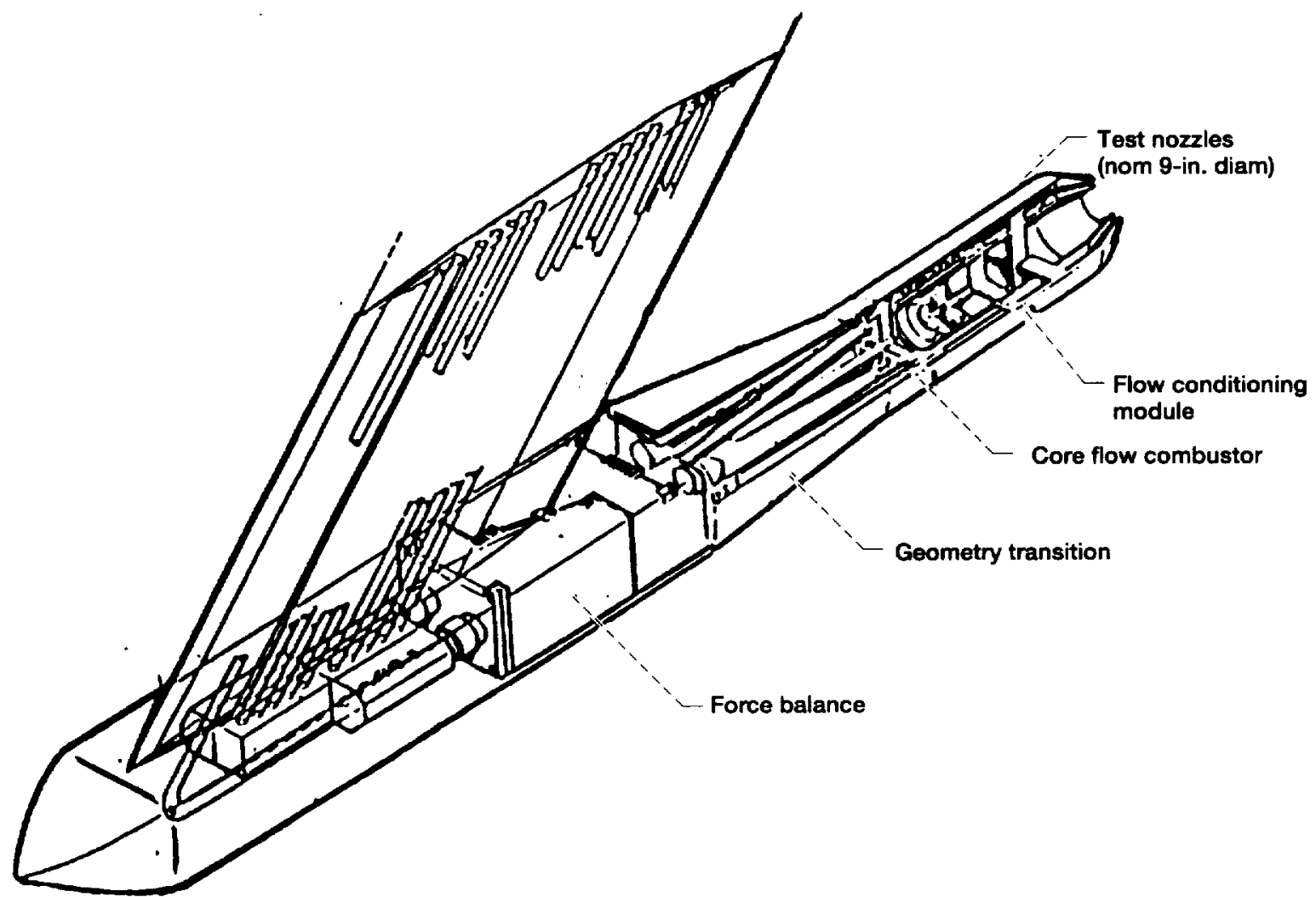

Figure 3.-Jet Exit Rig.

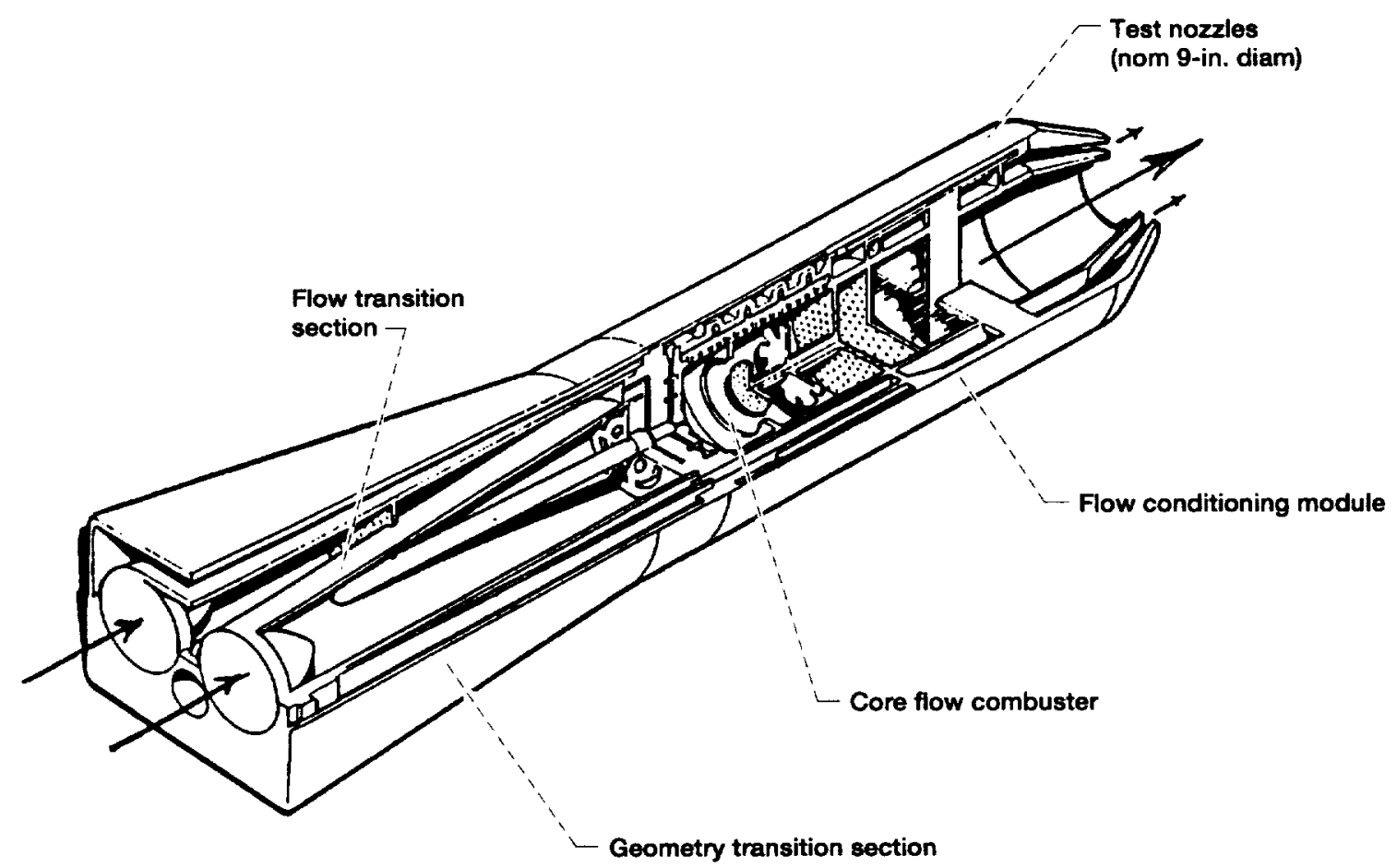

Figure 4.-Jet Exit Rig transition for axisymmetric nozzles. 


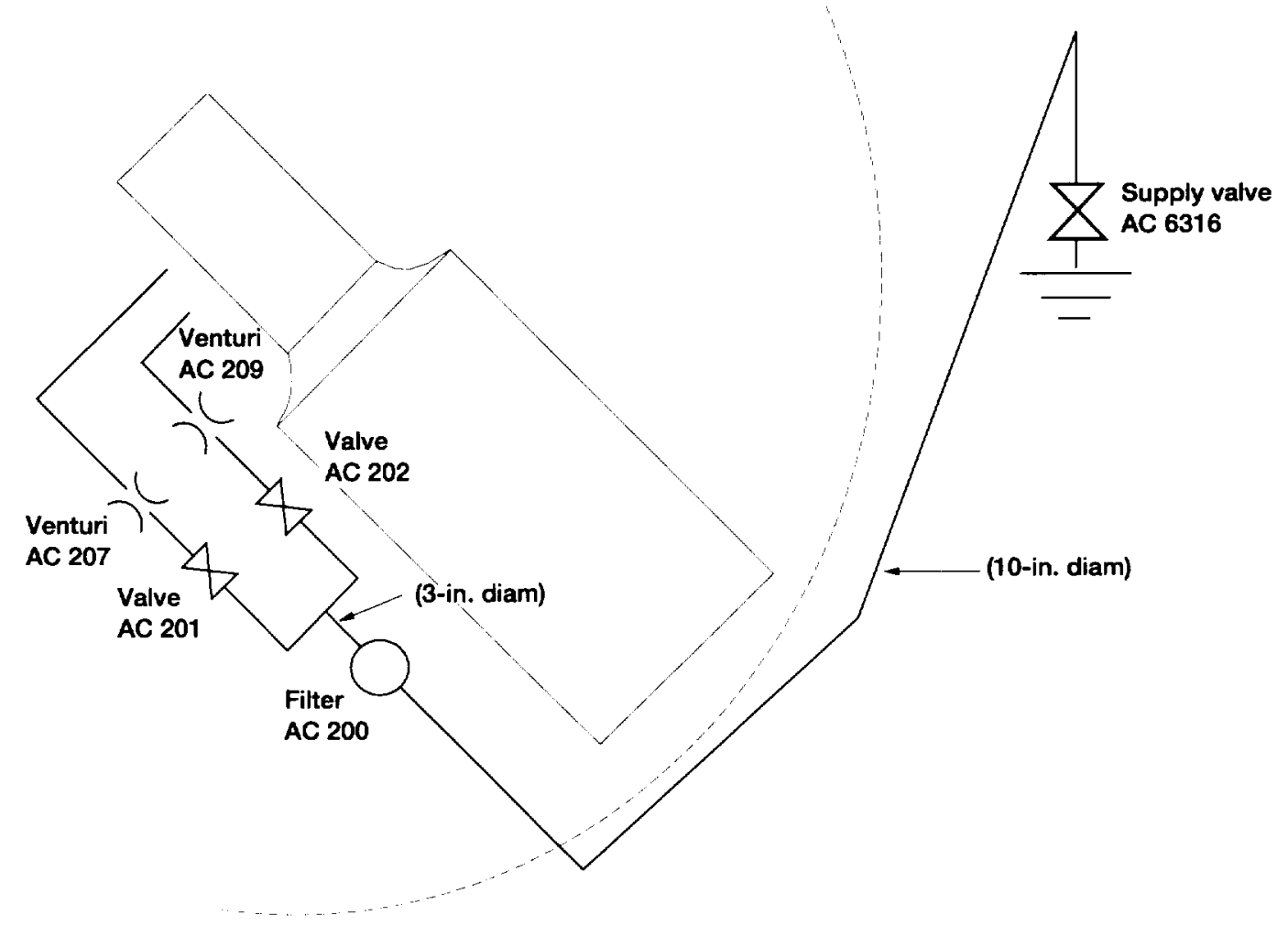

Figure 5.-NATR Compressed Air System layout.

TABLE II.-FLUID SUPPORT SYSTEMS AT NATR

\begin{tabular}{|c|c|c|c|}
\hline System & $\begin{array}{c}\text { Supply } \\
\text { pressure, } \\
\text { psig }\end{array}$ & $\begin{array}{c}\text { Number of } \\
\text { flows }\end{array}$ & Capacity \\
\hline Combustion air & 450 & 2 & $15 \mathrm{lb} / \mathrm{s}$ each \\
\hline Water/glycol cooling & 400 & 3 & $60 \mathrm{gal} / \mathrm{min}$ total \\
\hline $\mathrm{H}_{2}$ & 2400 & 1 & $\begin{array}{l}0.11 \mathrm{lb} / \mathrm{s} \\
140000 \mathrm{stdft}^{3}\end{array}$ \\
\hline Jet A & $\begin{array}{c}1000 \text { or } \\
40\end{array}$ & 1 & $\begin{array}{l}40 \mathrm{gal} / \mathrm{min} \text { or } \\
50 \mathrm{gal} / \mathrm{min}\end{array}$ \\
\hline $\mathbf{N}_{2}$ & 400 & as needed & $140000 \mathrm{stdft}^{3}$ \\
\hline Ignition system & & & \\
\hline $\mathrm{H}_{2}$ & 350 & 1 & $0.001 \mathrm{lb} / \mathrm{s}$ \\
\hline $\mathrm{O}_{2}$ & 390 & 1 & $0.011 \mathrm{lb} / \mathrm{s}$ \\
\hline Hydraulics & 2000 & as needed & $1 \mathrm{gal} / \mathrm{min}$ \\
\hline Service air/shop air & 125 & as needed & no flow \\
\hline
\end{tabular}

before being split into two separate flows through 3-in.diameter pipe. Each flow is controlled with a 3 -in. control valve (AC201 and AC202). These valves can be operated manually or automatically with a set-point control loop. Input to the loop comes from any analog signal, typically a process control pressure just downstream of the valve.
Each flow is measured with a choked flow measuring venturi sized to meet the test hardware requirements. The maximum flow rate through each 3 -in. line is $15 \mathrm{lb} / \mathrm{s}$. Airflow measurements are accurate to within \pm 0.5 percent of the measured flow. Connection to test hardware is through two 3 -in. pipe flanges.

Future plans for this system may provide $450 \mathrm{psig}$ compressed air heated to $600^{\circ} \mathrm{F}$.

\section{Cooling Liquid}

An equal mixture of water and glycol used for cooling is stored in an 800 -gal reservoir, which is designated as WE300 in Fig. 6. This mixture is pumped to the test article at a pressure of $400 \mathrm{psig}$ and a rate of $60 \mathrm{gal} / \mathrm{min}$ by the water pump designated as WE307. The cooling liquid connection to the test hardware is flexible and uses a 2-in.-diameter manifold. The cooling water system is used to cool high temperature test nozzles and combustors. Return flow is measured by the water venturis designated as WE329, WE330, and WE331. These venturis trigger alarms in the event of lost flow.

Return water flows through a heat exchanger (labeled WE335) that uses cooling water supplied through the from valve labeled WS301, and maintains the storage reservoir below a safe operating temperature of $170^{\circ} \mathrm{F}$. 


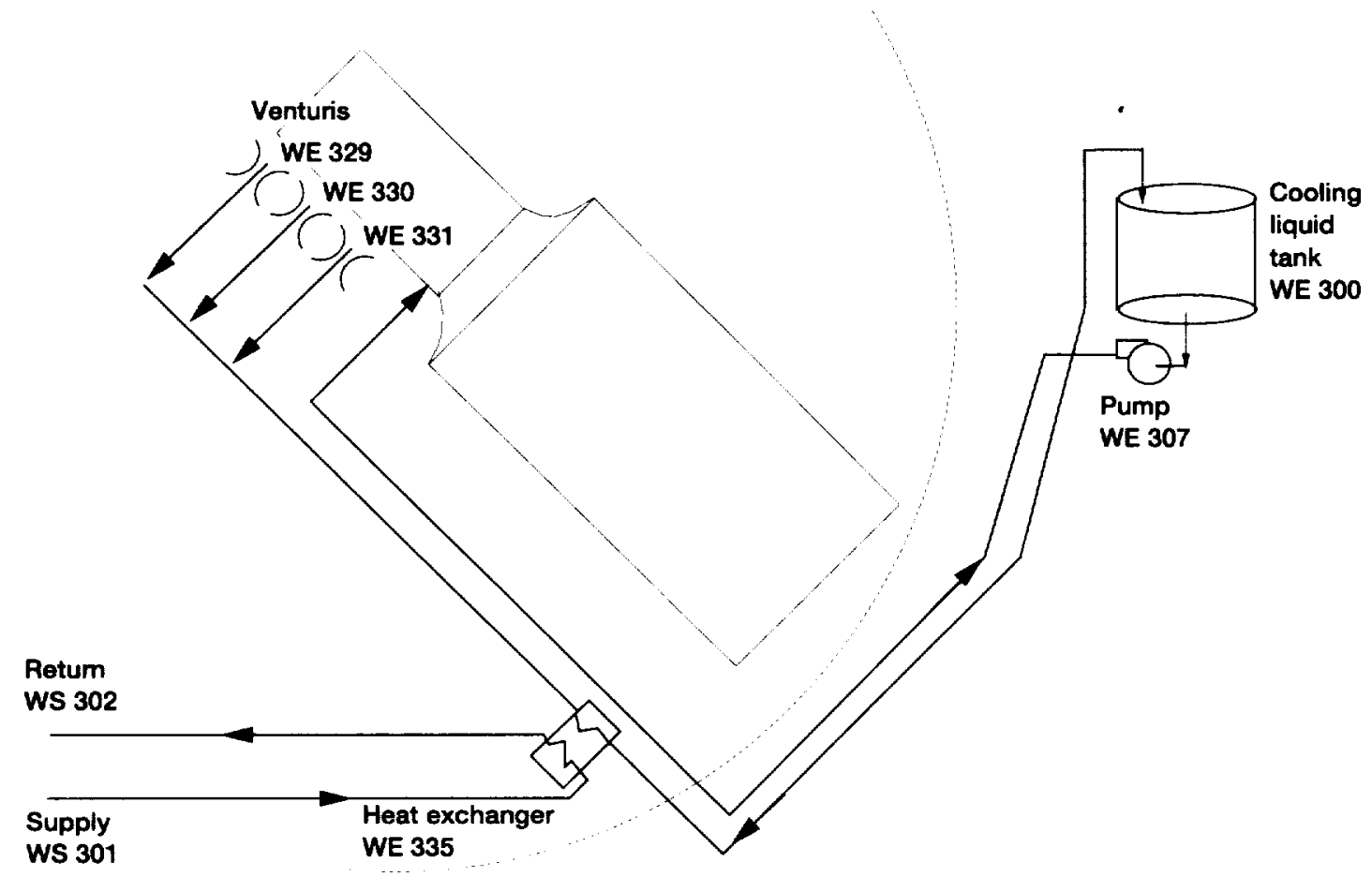

Figure 6.-NATR Cooling Water System layout.

\section{Hydrogen Fuel System}

Hydrogen fuel is used to heat combustion air for test nozzles, for the simulation of hot jet engine exhaust. The system layout is shown in Fig. 7. Hydrogen fuel is supplied by two $\mathrm{H}_{2}$ tube trailers, each containing $70000 \mathrm{stdft}^{3}$ of $\mathrm{H}_{2}$ at $2200 \mathrm{psig}$. One or both trailers can be used, depending on the fuel consumption requirements. The $\mathrm{H}_{2}$ is regulated at 1100 psig with two regulators (labeled FH128 and FH130) connected in series to protect against failure. A 304 series stainless steel is used throughout the system to reduce hydrogen embrittlement. Should any component fail, a flow restriction venturi (labeled FH132) prevents no more than $0.11 \mathrm{lb} / \mathrm{s}$ of $\mathrm{H}_{2}$ from escaping the trailers while pressure sensors initiate a shutdown.

Hydrogen, regulated at $1100 \mathrm{psig}$, is piped to the shut-off valve (labeled FH150) just outside the dome. Here, two vent valves, FH152 and FH153, allow for system venting and $\mathrm{N}_{2}$ purging. A vent stack extends $25 \mathrm{ft}$ above the surrounding installations.

From the external shut-off valve, the $\mathrm{H}_{2}$ fuel enters the dome and supplies the valve used for flow control (labeled FH155 in Fig. 7b). All piping to this point is welded and capable of operating at $2400 \mathrm{psig}$. The control valve and all downstream equipment are located inside a pressurized enclosure, which is purged with $\mathrm{N}_{2}$. This controlled enclosure provides an oxygen-free environment for nonwelded piping and components. Any escape of $\mathrm{H}_{2}$ into this enclosure is detected by either hydrogen or pressure sensors and initiates a shutdown at the supply valves. Valve FH155 controls $\mathrm{H}_{2}$ flow through choked flow measuring venturis FH161 and FH186. These venturis are arranged in a series/ bypass arrangement where only one shut-off valve is needed for venturi selection. The venturi labeled FH161 is used to measure high flow rates and the one labeled FH186 is used to measure low flow rates. From here, hydrogen fuel is routed to the combustion chamber of the Jet Exit Rig.

\section{Jet A Fuel System}

Jet $A$ fuel is not currently used for HSR testing at the Nozzle Acoustic Test Rig. However, this Power Lift Rig system is available for future use. The system is supplied by a single 5000-gal fuel trailer. Fuel is pumped from the trailer at a pressure of $50 \mathrm{psig}$ and flow rate of $60 \mathrm{gal} / \mathrm{min}$; flow can be boosted to a pressure of $1000 \mathrm{psig}$ and flow rate of $40 \mathrm{gal} /$ min. Minimal modifications are required to pipe Jet $A$ fuel to NATR.

\section{Nitrogen System}

Nitrogen is supplied by two 70000 -stdft ${ }^{3}$ tube trailers at 2200 psig. $\mathrm{N}_{2}$ is regulated at 400 psig for use at NATR. Safety procedures for the $\mathrm{H}_{2}$ system require $\mathrm{N}_{2}$ to purge all the $\mathrm{H}_{2}$ piping. Each section of the system can be independently purged, filled, and leak checked. The combustion chamber in the Jet Exit Rig is purged before and after each use.

\section{Combustion Wave Ignition System}

The Combustion Wave Ignition (CWI) system is an alternative to a conventional spark plug ignition system. It 


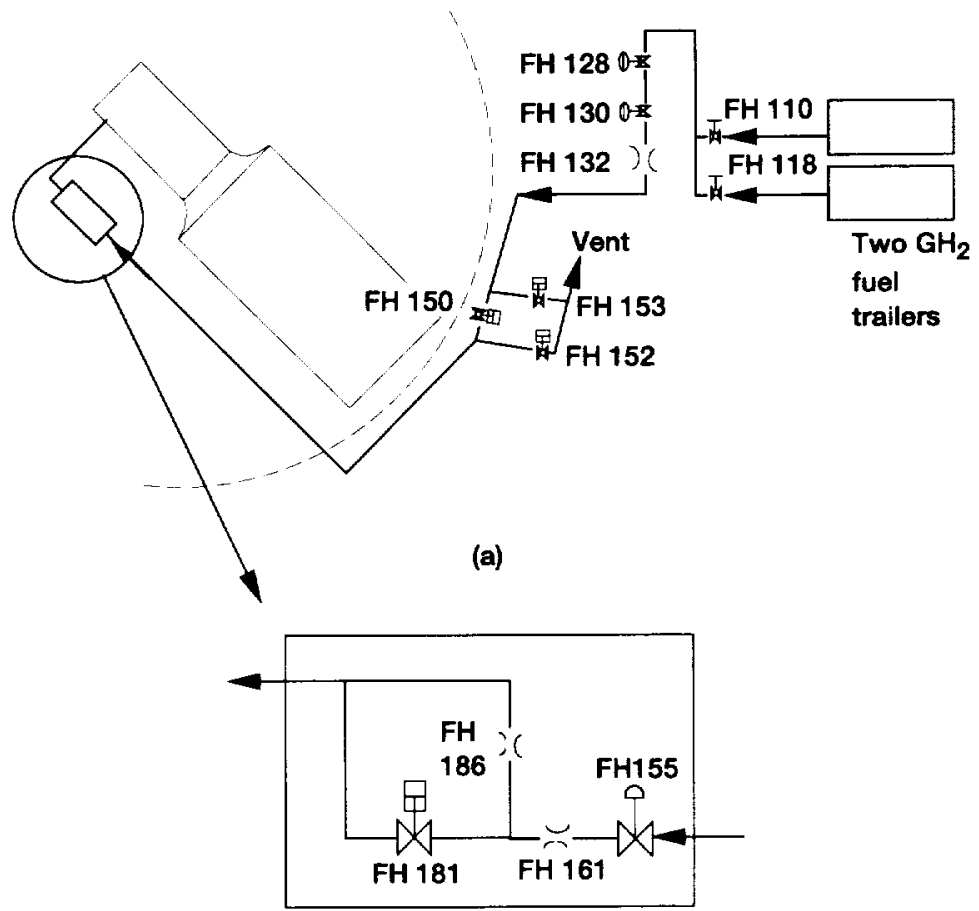

(b)

Figure 7.-NATR $\mathrm{H}_{2}$ System layout. (a) Schematic of $\mathrm{H}_{2}$ system. (b) Pressurized enclosure purged with $\mathrm{N}_{2}$.

can deliver high levels of energy to ignite high-speed fuel and air mixtures. The CWI uses a controlled detonation of $\mathrm{H}_{2}$ and $\mathrm{O}_{2}$. The detonation spark is delivered to the combustion chamber. This system is unique, as the detonation takes place external to the combustion chamber. This is a very flexible arrangement that allows a high energy spark to be delivered into a very small combustion area. Multiple sparks can be generated and delivered simultaneously.

$\mathrm{H}_{2}$ and $\mathrm{O}_{2}$ are supplied by standard cylinders that contain 220 stdft $^{3}$ at $2200 \mathrm{psig}$, as shown in Fig. 8. These bottles are each regulated to control supply pressures. Solenoid control valves (designated FH411 and XO411) are opened simultaneously with a programmable logic controller, to provide both fuel and oxidizer flow. Check valves (labeled FH412 and XO412) protect the system from the high back-pressure resulting from the controlled detonations. The $\mathrm{H}_{2}$ flow orifice (labeled FH413) allows flow rates to be set with upstream pressure. This system contains a 0.028 -in.diameter orifice, which supplies $\mathrm{H}_{2}$ at a rate of $0.00134 \mathrm{lb} / \mathrm{s}$ with an upstream pressure of $390 \mathrm{psig}$. The $\mathrm{O}_{2}$ flow orifice (labeled XO413) has a 0.042-in. diameter designed to supply $\mathrm{O}_{2}$ at a rate of $0.01072 \mathrm{lb} / \mathrm{s}$ at an upstream pressure of 350 psig.

Control valves FH411 and XO411 open to supply a pretimed mixture of $\mathrm{H}_{2}$ and $\mathrm{O}_{2}$. When these valves close, $\mathrm{N}_{2}$ control valves $N 411$ and $N 412$ open to allow $\mathrm{N}_{2}$ at $400 \mathrm{psig}$ to push the fuel and oxidizer into the mixing chamber, and afterward, into the combustion chamber. Flow restricting orifices $\mathrm{N} 414$ and $\mathrm{N} 416$ control the flow rate.

Orifices FH414 and XO414 create a pressure drop to reduce system back-pressure after a controlled detonation. From here, both the $\mathrm{H}_{2}$ and $\mathrm{O}_{2}$ combine in the mixing chamber. $\mathrm{A} \mathrm{N}_{2}$ buffer is used to push the mixture through the system. The ignitor contains a spark plug, located at the end of the mixer. When the plug is electrically excited, ignition occurs in the chamber. The flame front is pushed to the Jet Exit Rig combustion chamber through a 1/4-in. stainless steel tube. Tube lengths can be as long as $1 / 4 \mathrm{mi}$.

Details regarding the design, use, and safety issues of this system can be obtained from operations engineers in the Aeropropulsion Facilities and Experiments Division at NASA Lewis.

\section{Actuation Systems}

The following systems are available for the actuation of test hardware:

(1) A hydraulic system, located at the Powered Lift Rig, is capable of $1 \mathrm{gal} / \mathrm{min}$ flow at $2000 \mathrm{psig}$.

(2) Shop air is also available at 125 psig for actuation of pneumatic devices.

(3) Electrical power is available at $125 / 250 / 440 \mathrm{~V}$. 


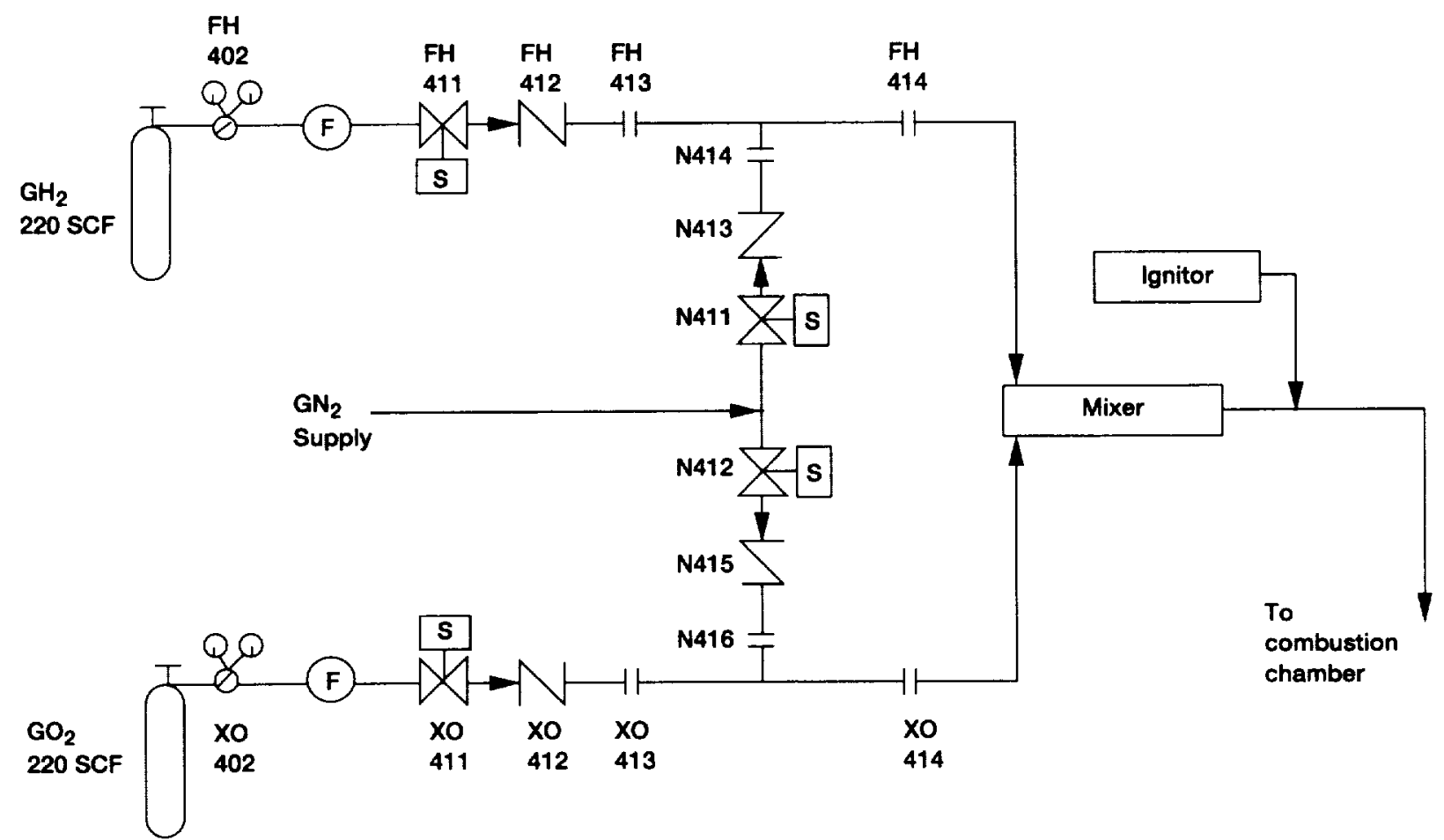

Figure 8.-NATR Combustion Wave Ignition System layout.

\section{Instrumentation and Data Systems}

For the collection of aerodynamic measurements, NATR is equipped with a steady-state data acquisition system. The system, designated as ESCORT D, is widely used at NASA Lewis and consists of a Digital Equipment Corporation (DEC) MicroVAX II located at the facility. This system is connected to Lewis' central scientific VAX cluster for software development and testing. Capabilities of this system include on-line processing of inputs for calculation and display, displays for operational and research data, online color graphics and charting, and laser printer output. Programming is provided by the Computer Services Directorate at NASA Lewis.

Inputs for ESCORT D include a multiplexing unit, an electronic pressure scanning system, and a probe actuator control system. The number of pressure, temperature, and strain gage inputs available are constantly upgraded to meet the requirements of new test programs.

The multiplexer provides digitizing of analog data signals, such as thermocouples, pressure transducers, and load cells. Digitizing rates can accommodate up to one scan of all inputs per second. Gain ranges for analog inputs extend from 5 to $5120 \mathrm{mV}$, and are programmable over 11 ranges. The thermocouple inputs are gathered from isothermal reference units; type $K$ and type $R$ thermocouples are commonly used. Strain gage inputs commonly include load cells and pressure transducers. These devices are calibrated by a computer-programmed calibration, which adjusts the slope and sensitivity of the device based on real-time output.
Multiplexer inputs can include atmospheric conditions such as ambient temperature, pressure, humidity, wind speed, and wind direction.

The electronically scanned pressure (ESP) system is connected to ESCORT D. Pressures are digitized and sent to ESCORT through a dedicated personnel computer (PC) controller. NATR supports three different pressure measurement ranges, $\pm 15 \mathrm{psig}, \pm 100 \mathrm{psig}$, and $\pm 500 \mathrm{psig}$. The system is continuously calibrated using a DIGIQUARTZ* transducer standard and a three point calibration, which ensures 0.1 percent full scale accuracy.

The Probe Actuator Control System (PACS) probe controller is a PC-based system for operating stepper motors. These motors are often used to actuate aerodynamic arrays of pressure sensing probes (rakes). Position information from this control system is sent to the ESCORT system and can be recorded as data.

\section{Acoustic Capabilities}

A geodesic dome surrounds two test rigs, the Nozzle Acoustic Test Rig and the Powered Lift Rig. The Powered Lift Rig, used to test Short Takeoff and Vertical Landing nozzle concepts, typically generates noise levels of $130 \mathrm{dBA}$ or more. The dome was constructed to protect the community surrounding NASA Lewis and provides a 20-dBA reduction in noise. Since its installation, complaints about test noise have significantly decreased. The dome has a 62 -ft radius and is built on an aluminum frame, which is covered with two layers of aluminum panels. The 
first layer is 0.19 -in. thick and the second is 0.07 -in. thick. Sandwiched between the layers is 2 in. of glass fiber insulation. The entire structure is weather sealed with a layer of 0.05 -in. thick aluminum panels. This design conforms to a Sound Transmission Coefficient (STC) of 55. The construction of the dome wall can be seen in Fig. 9.

The inlet for secondary air used in the NATR ejector was built as an integral part of the dome. Secondary air is drawn through a doorway and exhausts through a 40 -ft opening. The inlet doorway is covered to form a tunnel for ejector secondary air (Fig. 1). This tunnel is acoustically treated to shield airflow noise from the interior of the dome, and from the community.

The dome provides an ideal location for desired HSR nozzle tests. The inside of the structure is designed to provide an anechoic environment for acoustic measurements. In addition, the walls prevent extraneous noise from entering the dome and contaminating acoustic data. The anechoic installation involved mounting wedges, 2 - $\mathrm{ft}$ thick

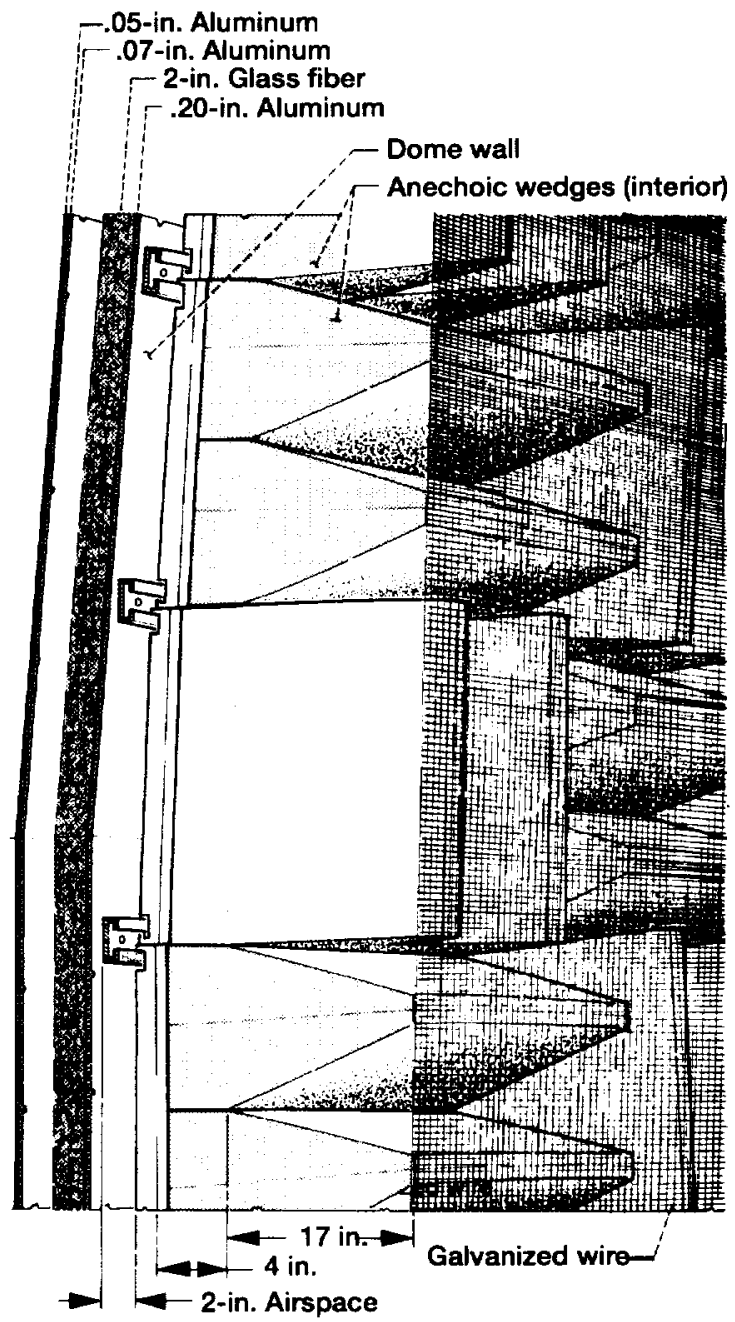

Figure 9.-Construction detail for the geodesic dome. from base to tip, throughout the dome interior. These wedges are constructed of glass fiber $\left(3 \mathrm{lb} / \mathrm{ft}^{3}\right)$ covered with glass cloth. Hardware cloth covers the exterior of each wedge for added rigidity. The wedge installation on dome walls is illustrated in Fig. 9.

An unforeseen problem arose after installation of the acoustic wedges; they became a haven for birds. To solve this problem, a second layer of hardware cloth (galvanized wire) was installed over the tips of the wedges, as shown in Fig. 9. The hardware cloth is invisible to acoustic measurements taken inside the dome. This effectively eliminated access to the wedges and prevented bird nesting.

Complete anechoic treatment also includes wedges to cover the NATR and the dome floor. This treatment consists of wedges similar to those used on the dome wall. They cover all NATR ejector hardware, reducing acoustic reflections. Wedges are also installed on pallets to cover the concrete floor of the dome. These installations combine to provide an anechoic environment for nozzle testing. Future reporting will document the anechoic performance inside the dome and levels of community noise protection.

\section{Acoustic Data Systems and Instrumentation}

Acoustic data systems at NATR support up to 32 channels of digital recording and storage. Twelve of these channels can be recorded onto analog tape for storage and later use. Most front-end acoustic instrumentation consists of 1/4- and 1/2-in. microphones, pre-amplifiers, and power supplies. Microphones are mounted in the dome on $10-\mathrm{ft}$ tall pole stands, which are bolted to the floor. These 29 pole stands are located at a $51-\mathrm{ft}$ radius with a $5^{\circ}$ spacing. Additional pole stands are available to allow flexible location of microphones inside the dome. Analog signals from the microphones are sent to an analog tape system, or to analog-to-digital converters for storage on a computer.

The data collection computer is capable of storing digital signals on an internal hard-disk drive and transferring them to digital tape. In this manner, data can be stored for future analysis on this, or a similar system. Analysis software is available for postprocessing of data.

\section{Scheduling of Tests}

Further information about the use and scheduling of the NATR should be directed to the facility manager of the Aeropropulsion Facilities and Experiments Division at NASA Lewis Research Center. To assist in effective scheduling, the following information is requested:

(1) Test program objectives

(2) Test model description

(3) Instrumentation requirements 
(4) Test schedule requirements

(5) Test requirements

(6) Data reduction requirements

\section{Summary of Results}

The Nozzle Acoustic Test Rig was built at the NASA Lewis Research Center to support the High Speed Research program. The facility is capable of measuring the acoustic and aerodynamic performance of HSR nozzles. HSR nozzle concepts are used to study the reduction of noise levels during takeoff and low-speed flight. These concepts are being developed for the next generation of aircraft for High Speed Civil Transport.

Located inside a 62 - $\mathrm{ft}$ radius dome, the NATR is a 53-in.diameter free-jet. Airflow is generated by an air ejector, which uses $125 \mathrm{lb} / \mathrm{s}$ of compressed air at $125 \mathrm{psig}$, to achieve $375 \mathrm{lb} / \mathrm{s}$ total airflow at Mach 0.3. To obtain acoustic data, free-jet noise levels must be 20 to $30 \mathrm{~dB}$ below HSR test nozzle levels. The air ejector is designed with an acoustic liner to meet this constraint.

Test nozzles, attached to NASA Lewis' Jet Exit Rig, are mounted approximately $2 \mathrm{ft}$ downstream of the free-jet exit in the center of the plume. The Jet Exit Rig is capable of supplying nozzle pressure ratios up to 5.0 at $2000^{\circ} \mathrm{R}$. To obtain these conditions, 450 psig air, delivered at a maximum rate of $15 \mathrm{lb} / \mathrm{s}$, and $\mathrm{H}_{2}$ fuel, delivered at a maximum rate of $0.11 \mathrm{lb} / \mathrm{s}$, are supplied to the rig.
Data collection systems are available at NATR to collect force data, pressures, temperatures, atmospheric conditions, and acoustics. The steady-state data collection system, called the ESCORT D system, is capable of sampling analog temperature and strain gage measurements. Steadystate pressure measurements can also be made. Data are transferred to NASA Lewis' scientific VAX cluster for analysis. Acoustic data are collected on analog tape or digitized for storage and analysis on a dedicated computer located at the facility.

An acoustic dome surrounds the facility, built to protect the community from the high noise levels generated during nozzle testing. The dome construction provides approximately $20-\mathrm{dBA}$ protection from nozzle noise levels. To enhance acoustic measurements, the inside wall of the dome is covered with fiberglass wedges that are $2 \mathrm{ft}$ from base to tip. The base of the wedges are attached to the dome ceiling with the tips pointing downward. This configuration reduces interior reflections.

Designed specifically for acoustic and aerodynamic testing of advanced nozzle concepts, the NATR can be used to test a variety of aircraft technologies under low-speed flight and takeoff conditions.

\section{$\underline{\text { Reference }}$}

1. Long, M.J., "Experimental Investigation of an Ejector Powered Free-Jet Facility,” AIAA-92-3569, July 1992. 

Public reporting burden for this collection of information is estimated to average 1 hour per response, including the time for reviewing instructions, searching existing data sources gathering and maintaining the data needed, and completing and reviewing the collection of information. Send comments regarding this burden estimate or any other aspect of this collection of information, including suggestions for reducing this burden, to Washington Headquarters Services, Directorate for Information Operations and Reports, 1215 Jefferson Davis Highway, Suite 1204, Arlington, VA 22202-4302, and to the Office of Management and Budget, Paperwork Reduction Project (0704-0188), Wastington, DC 20503.

\begin{tabular}{|l|l|l|} 
1. AGENCY USE ONLY (Leave blank) & 2. REPORT DATE & 3. REPORT TYPE AND DATES COVERED
\end{tabular}

\section{TITLE AND SUBTITLE}

April 1994

Technical Memorandum

The Nozzle Acoustic Test Rig; An Acoustic and Aerodynamic Free-Jet Facility

\section{AUTHOR(S)}

Raymond S. Castner

\section{PERFORMING ORGANIZATION NAME(S) AND ADDRESS(ES)}

8. PERForming ORganization

National Aeronautics and Space Administration

Lewis Research Center

Cleveland, Ohio 44135-3191
WU-505-62-84 REPORT NUMBER

5. FUNDING NUMBERS

\section{$\mathrm{E}-\mathbf{8 4 8 5}$}

\section{SPONSORINGMONITORING AGENCY NAME(S) AND ADDRESS(ES)}

National Aeronautics and Space Administration

Washington, D.C. 20546-0001
10. SPONSORINGMONITORING AGENCY REPORT NUMBER

NASA TM-106495

AIAA-94-2565

\section{SUPPLEMENTARY NOTES}

Prepared for the 18th AlAA Aerospace Ground Testing Conference sponsored by the American Institute of Aeronautics and Astronautics, Colorado Springs, Colorado, June 20-23, 1994. Responsible person, Raymond S. Castner, organization code 2820 , (216) 433-5657.

12a. DISTRIBUTIONAVAILABILITY STATEMENT 12b. DISTRIBUTION CODE

Unclassified - Unlimited

Subject Category 05 and 09

\section{ABSTRACT (Maximum 200 words)}

The Nozzle Acoustic Test Rig (NATR) was built at NASA Lewis Research Center to support the High Speed Research Program. The facility is capable of measuring the acoustic and aerodynamic performance of aircraft engine nozzle concepts. Trade-off studies are conducted to compare performance and noise during simulated low-speed flight and takeoff. Located inside an acoustically treated dome with a 62-ft radius, the NATR is a free-jet that has a 53-in. diameter and is driven by an air ejector. This ejector is operated with $125 \mathrm{lb} / \mathrm{s}$ of compressed air, at $125 \mathrm{psig}$, to achieve 375 $\mathrm{lb} / \mathrm{s}$ at Mach 0.3. Acoustic and aerodynamic data are collected from test nozzles mounted in the free-jet flow. The dome serves to protect the surrounding community from high noise levels generated by the nozzles, and to provide an anechoic environment for acoustic measurements. Information presented in this report summarizes free-jet performance, fluid support systems, and data acquisition capabilities of the NATR.

\section{SUBJECT TERMS}

Nozzles; Acoustic; Engine testing laboratories; Free-jet; Test facilities

15. NUMBER OF PAGES

17. SECURTY CLASSIFICATION OF REPORT

Unclassified

18. SECURITY CLASSIFICATION
OF THIS PAGE
Unclassified
19. SECURITY CLASSIFICATION OF ABSTRACT Unclassified
20. LIMITATION OF ABSTRACT 